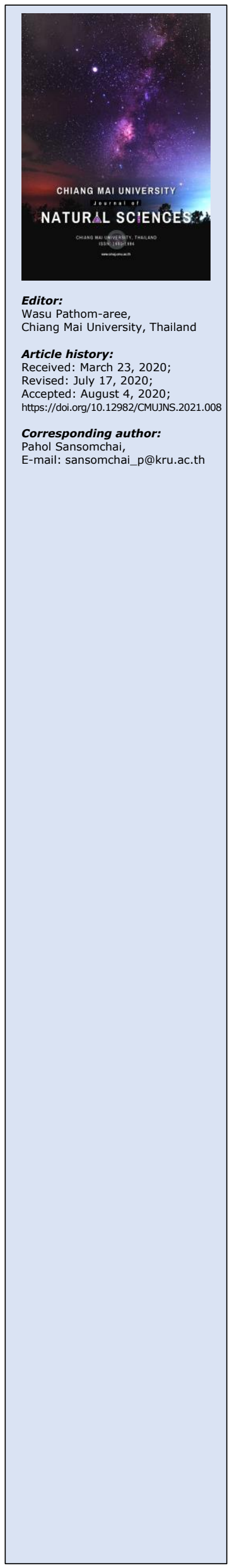

Research article

\title{
Melientha suavis Pierre. Extract: Antioxidant and Sunscreen Properties for Future Cosmetic Development
}

\author{
1 Faculty of Science and Technology, Kanchanaburi Rajabhat University, Kanchanaburi 71190, Thailand \\ 2 Division of Chemistry, School of Science, University of Phayao, Phayao 56000, Thailand \\ 3 Institute of Research and Development, Lampang Rajabhat University, Lampang 52100, Thailand
}

Pahol Sansomchai ${ }^{1,3,{ }^{*}}$, Kanlaya Jumpatong ${ }^{2}$, Chaipat Lapinee ${ }^{2}$, and Kanchana Utchariyajit ${ }^{1}$

Abstract The ultimate aim of this study was to evaluate antioxidant activities using DPPH and ABTS assay and antioxidant substances of Melientha suavis Pierre (Melientha) extracts with ethanol (EtOH) and subsequent partition with hexane, dichloromethane $\left(\mathrm{CH}_{2} \mathrm{Cl}_{2}\right)$, ethyl acetate (EtOAc) and distilled water (W). The Melientha extract was assessed the sunscreen activities by sun protection factor which was compared with octyldimethyl PABA. Additionally, the stability test of Melientha extracts added in the cosmetic base-formula was investigated. The sun protection substances of Melientha extracts were determined by GC-MS analysis. Among the extract and fractions, the ethanolic extract showed the highest activities. The $\mathrm{IC}_{50}$ of Melientha extract to free radical scavenging determined by DPPH assay and ABTS assay were $53.20 \pm 7.37 \mu \mathrm{g} / \mathrm{ml}$ and $64.17 \pm 5.76 \mu \mathrm{g} / \mathrm{ml}$, respectively. The total phenolic compound of ethanol extract was $149.87 \pm 2.72$ $\mathrm{mg} \mathrm{GE} / \mathrm{g}$ of ext and total flavonoid content was $51.60 \pm 4.12 \mathrm{mg} \mathrm{CE} / \mathrm{g}$ of ext. The sun protection factor (SPF) of ethanol extract was $26.61 \pm 0.10$. Cinamate and its derivative which were claim as sunscreen substance was found by GC-MS analysis of Melientha ethanol extract.

Keywords: Antioxidant activity, GC-MS, Cream, Natural product

Citation: Sansomchai, P., Jumpatong, K., Lapinee, C., and Utchariyajit, K. 2021. Melientha suavis Pierre. Extract: antioxidant and sunscreen properties for future cosmetic development. CMUJ. Nat. Sci. 20(1): e2021008 


\section{INTRODUCTION}

Melientha suavis Pierre (Melientha) is an edible plant which can be found in the forests of Thailand and Southeast Asia. Melientha is becoming an important ingredient to certain for Thai main dish, especially young leaves and their stems. Melientha is commonly found in the Lamphun province of Thailand. The phytochemical components such as a group of alkaloids, carbohydrates, coumarins, flavonoids, saponins and tannins were found in the extracts of Melientha. The nutritional composition of Melientha was claimed with high in beta carotene, vitamin $\mathrm{C}$, phosphorus and calcium (Charoenchai et al., 2015). One's study showed Melientha extracts reduced mutation of somatic cells by ethyl carbamate (Sukprasansap et al., 2010). In addition, the average clear zone of inhibition of Fusarium oxysporum and Xanthomonas campestris after incubating with Melientha extract has more than $10 \mathrm{~mm}$ (Hatthakitpanichakul and Tangjitjaroenkul, 2007). The studies of antioxidant activities, total phenolic and flavonoid contents of Melientha have been showed in the other part of Thailand (Charoenchai et al., 2013; Charoenchai et al., 2015). Previous studied suggested that phenolic and flavonoids compounds are protect against UV-B induced ROS (Hu et al., 2017).

Sun light is most affects to human skin, cause sun burn, skin cancer, skin pigmentation and aging. These are several effects of UV radiations. Therefore, the necessary of sunscreen formulating development for protecting sun burn, suntan, skin cancer or skin aging are required. To protect UV radiation various substances were used for verifying the Sun Protection Factor (SPF) (Skotarczak et al., 2015). The goal of sunscreen formulation is to block UV-rays and increase the level of protection from the UV-rays. Many components such as flavonoids, phenolic compounds show the UV protection effect by UV rays absorption capacities (UV-A region) (Hu et al., 2017). Cell mutation, DNA damage, hormone alteration and eczema like allergic reaction are some adverse effects of the synthetic sun $\neg$ screen agents. Sunscreen formulations available in market do not have properties like wound healing, anti-inflammatory and antiageing. Against free radical mediated skin damages cannot be cured until and unless free radical scavengers are not available in photo protective products (Parzonko and Kiss, 2019).

Since, there is less information about the medicinal properties of Melientha for cosmetic product. This study was to search the natural ingredients from Melientha extract and its fractions for skin care cosmetic. The antioxidant activities and amount of antioxidant substances of Melientha extract and its fractions were screening for further study. Positive findings would indicate for sun protection factor and gas chromatography-mass spectrometry. The potential of Melientha extract or its fractions will used for developing accessible and affordable value added cream using ingredients extracted from natural sources rather than synthetic drugs.

\section{MATERIALS AND METHODS}

\section{Plant materials}

The mature leaves of Melientha plant was collected from Lamphun, the most northern province of Thailand. The plant was verified using The Plant List (http://www.theplantlist.org). The leaves were cleaned and dried in an oven at $40^{\circ} \mathrm{C}$, then stored at $-20^{\circ} \mathrm{C}$ until being used.

\section{Preparation of ethanolic crude extract}

One kilogram of dried samples were grounded into powder and macerated in $4 \mathrm{~L}$ of $80 \%(\mathrm{v} / \mathrm{v})$ ethanol $(\mathrm{EtOH})$ for $24 \mathrm{~h}$ at room temperature. The extraction was performed twice under the same conditions. Chlorophyll was removed by the charcoal adsorption method. Then, the chlorophyll-free extracts were filtered through Whatman's No.1 filter paper and the solvent was removed using a vacuum rotary evaporator at room temperature. The concentrated aqueous portion was lyophilized into a powder and further partitioned using four different solvents including hexane, dichloromethane $\left(\mathrm{CH}_{2} \mathrm{Cl}_{2}\right)$, ethyl acetate $(\mathrm{EtOAC})$ and distilled water (W) (Figure 1). 
The ethanolic extract and fractions with the highest antioxidant activity would then be used for subsequent experiments.

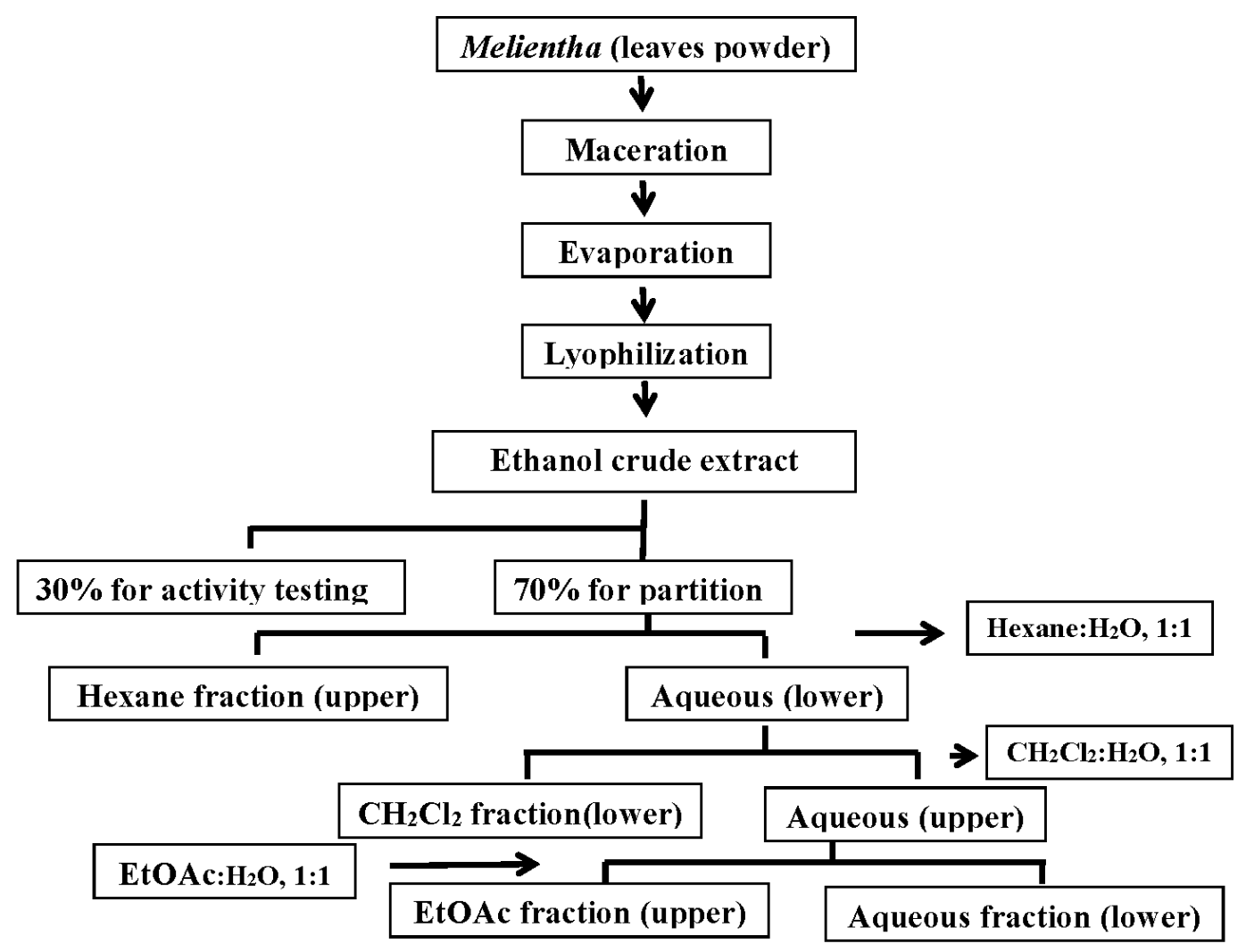

Figure 1. The diagram of Melientha extraction and partition.

\section{Evaluation of antioxidant activities from crude extract}

The free radical scavenging activities of Melientha ethanol extract and fractions were measured by two methods. The DPPH inhibition assay and the ABTS inhibition assay was performed and slightly modified as described by previous studies (Abramovič et al., 2018; Saansoomchai et al., 2018). With treatments of various concentrations of the ethanol extract and fractions, the decrease in absorbance was measured at $517 \mathrm{~nm}$ for the DPPH assay and $735 \mathrm{~nm}$ for the ABTS assay and the IC $_{50}$ values were also reported.

\section{Determination of total phenolic and total flavonoid contents from crude extract}

Total phenolic content (TP) and total flavonoid content (TF) were determined using the Folin-Ciocalteu assay and aluminium chloride colorimetric assay, respectively, as was described by previous studies with minor modifications (Saansoomchai et al., 2018). Quantification was expressed as milligram gallic acid equivalent per gram extract ( $\mathrm{mg} \mathrm{GE} / \mathrm{g}$ ) for TP and milligram catechin equivalent per gram extract (mg CE/g) for TF. Three replications were performed for each experiment. The extract that gave the highest antioxidant activities and antioxidant compounds will be monitored the evaluation of formulation, Sun protection factor (SPF).

\section{Evaluation of formulation}

Physical parameters. Appearance, color and homogeneity of each formulated cream (Table1) are determined. 
Table 1. Formula for development of photo protective cream formulations.

\begin{tabular}{llllll}
\hline Ingredients & F-1(g) & F-2 (g) & F-3 (g) & F-4 (g) & F-5 (g) \\
\hline Extract & 0.000 & 0.125 & 0.250 & 0.500 & 1.000 \\
Cetostearyl alcohol & 5.000 & 5.000 & 5.000 & 5.000 & 5.000 \\
Strearic acid & 2.000 & 2.000 & 2.000 & 2.000 & 2.000 \\
PEG-200 & 2.000 & 2.000 & 2.000 & 2.000 & 2.000 \\
Cetyl alcohol & 1.000 & 1.000 & 1.000 & 1.000 & 1.000 \\
Phenoxyethanol & 1.000 & 1.000 & 1.000 & 1.000 & 1.000 \\
Carbopol 940 & 0.500 & 0.500 & 0.500 & 0.500 & 0.500 \\
Disodium EDTA & Qs. & Qs. & Qs. & Qs. & Qs. \\
Triethanolamine & 0.500 & 0.500 & 0.500 & 0.500 & 0.500 \\
\hline
\end{tabular}

Distilled water qs. to $100 \mathrm{mg}$

The formulated cream procedure was following:

Step 1: Aqueous phase

Part 1. Disodium EDTA, phenoxyethanol and extracts were weighed accurately and dissolved in some of distilled water.

Part 2. The remain distilled water was dispersed with carbopol 940 while heat up to $70^{\circ} \mathrm{C}$ to swelling using a homogenizer.

Step 2: Oil phase

Steric acid, cetyl alcohol, and cetostearyl alcohol were weighed accurately, mixed and heated to $70^{\circ} \mathrm{C}$. Then mix oil phase to part 2 of aqueous phase at $70^{\circ} \mathrm{C}$ with continuous stirring for 30 min till was homogenized and uniformed. Part 1 of aqueous phase was added in the formulated cream when it cools down to $40^{\circ} \mathrm{C}$. The formulated cream will be used for further experiment.

For physical parameters were followed by Donglikar and Deore method with minor change (Donglikar and Deore, 2017).

Thermal stability. The formulated cream was tested at $60-70 \% \mathrm{RH}$ and $37.0 \pm$ $1.0^{\circ} \mathrm{C}$ room. The thermal cycle was cooling and heating $\left(0^{\circ} \mathrm{C}\right.$ to $-4^{\circ} \mathrm{C}$ and room temperature) for 4 cycles. To pass the test there should not be separation oil or liquidify in the cream.

pH determination. Formulated cream might have variety of $\mathrm{pH}$ mostly ranging from 5 to 9. In general, it has a pH 6 to 9 . The formulated creams were diluted to $10 \%$ dilution with distilled water. The ranging $\mathrm{pH}$ of mixtures was determined with $\mathrm{pH}$ meter.

Viscosity. Viscosities of creams were measured by the Brookfield viscometer (Applied Scientific Instruments Co., Ltd., Dial reading viscometer, Thailand). The correct spindle was selected (spindle no. 4) for the given product then the operating condition was setup. Then the viscosity was measured directly at $6 \mathrm{rpm}$ speed by keeping the torque constant.

\section{Sun protection factor (SPF)}

Approximately $100 \mathrm{mg}$ of each formulated cream was applied and spread on the $56 \mathrm{~cm} 2$ area to obtained a sample film thickness of $2 \mu \mathrm{l} / \mathrm{cm}^{2}$ on Transpore Tape to get an even film as suggested in the operation manual of the UV-2000S Ultraviolet Transmittance Analyzer (Spectral Technology Instrument Co., Ltd., Thailand) for the sample preparation and application techniques. The tropically natural formulation was evaluated for in vitro SPF determination. The commercial sunscreen agent was octyl dimethyl paba (PABA). The ethanol crude extract or fractions of Melientha that gave the highest SPF value will be monitored by gas chromatography-mass spectrometry. 


\section{Gas chromatography-mass spectrometry (GC-MS) analysis}

The ethanol extract or fractions that showed the best screening test and the best SPF value were investigated components with GC-MS. The chemical compositions of the sample $(1 \mu \mathrm{l})$ were analyzed using a Hewlett Packard model HP6890 gas chromatograph (Agilent Technologies, Palo Alto, CA, USA) equipped with an HP-5MS (5\% phenylpolymethylsiloxane) capillary column ( $30 \mathrm{~m} \times 0.25 \mathrm{~mm}$ i.d., film thickness 0.25 $\mu \mathrm{m}$; Agilent Technologies, USA) interfaced to an HP model 5973 mass-selective detector of split mode. The oven temperature was initially held at $60^{\circ} \mathrm{C}$ and then increased by $3^{\circ} \mathrm{C} / \mathrm{min}$ to $230^{\circ} \mathrm{C}$. The injector and detector temperatures were 250 and $280^{\circ} \mathrm{C}$, respectively. Purified helium was used as the carrier gas at a flow rate $1 \mathrm{ml} / \mathrm{min}$. EI mass spectra were collected at $70 \mathrm{eV}$ ionization voltages over the range of $\mathrm{m} / \mathrm{z} 29-300$. The electron multiplier voltage was $1150 \mathrm{~V}$. The ion source and quadrupole temperatures were set at $230^{\circ} \mathrm{C}$ and $150^{\circ} \mathrm{C}$, respectively. The relative percentage of the mass spectra of major components with the reference mass spectra in the Wiley 275 and NISTO5 databases were compared (more than $80 \%$ of homology was accepted).

\section{Statistical analysis}

Each experiment was performed in triplication. All values are presented as a mean value (mean \pm SD). The statistically significant differences between the means of the samples were calculated by one-way ANOVA. The differences were considered as significant at a level of $P<0.05(*)$.

\section{RESULTS}

\section{Melientha crude extracts against ABTS and DPPH radicals and their total phenolic (TP) and total flavonoid (TF) contents}

In this study, Melientha leaves were collected from Lamphun Province. The antioxidant activities of Melientha crude extracts were measured by determining their abilities to scavenge DPPH and ABTS radicals. As shown in Table 2, the antioxidant activities of Melientha ethanol extract and fractions at $0-200 \mu \mathrm{g} / \mathrm{ml}$ were found to inhibit the ABTSradical and DPPH-radical in a dose dependent manner when compared with Trolox as a positive control and ascorbic acid, respectively. Melientha extract in the ethanol extract at $200 \mu \mathrm{g} / \mathrm{ml}$ displayed the highest inhibitory effect when it was able to inhibit ABTS and DPPH radical, followed by $\mathrm{W}$, EtOAC, $\mathrm{CH}_{2} \mathrm{Cl}_{2}$ and hexane fraction at the same levels of concentration. This finding well agreed with the evaluation of total phenolic contents and total flavonoid contents of each fraction that are shown in Table 2. The extract and fractions of Melientha were correlated to antioxidation against ABTS and DPPH radicals.

Table 2. IC 50 of the Melientha extract and fractions against ABTS and DPPH radicals and their total phenolic (TP) and total flavonoid (TF) contents.

\begin{tabular}{|c|c|c|c|c|c|}
\hline \multirow{2}{*}{\multicolumn{2}{|c|}{$\begin{array}{l}\text { Extract and } \\
\text { Fractions }\end{array}$}} & \multicolumn{2}{|c|}{$\mathrm{IC}_{50}(\mu \mathrm{g} / \mathrm{ml})$} & \multirow{2}{*}{$\begin{array}{l}\text { TP } \\
\text { (mg GE/g of } \\
\text { ext) }\end{array}$} & \multirow{2}{*}{$\begin{array}{l}\text { TF } \\
(\mathrm{mg} \mathrm{CE} / \mathrm{g} \text { of ext) }\end{array}$} \\
\hline & & ABTS assay & DPPH assay & & \\
\hline Ascol & bic acid & $53.48 \pm 3.28$ & $38.94 \pm 3.32$ & - & - \\
\hline & Trolox & $8.95 \pm 1.07$ & $6.31 \pm 1.73$ & - & - \\
\hline \multicolumn{6}{|c|}{ Melientha } \\
\hline EtOH & & $64.17 \pm 5.76$ & $53.20 \pm 7.37$ & $149.87 \pm 2.72$ & $51.60 \pm 4.12$ \\
\hline- & Hexane & $>200^{*}$ & $>200 *$ & - & \\
\hline- & $\mathrm{CH}_{2} \mathrm{Cl}_{2}$ & $>200 *$ & $>200 *$ & $10.18 \pm 1.84$ & $2.05 \pm 0.14$ \\
\hline- & EtOA $_{c}$ & $>200 *$ & $>200 *$ & $29.30 \pm 1.98$ & $4.18 \pm 0.64$ \\
\hline- & W & $183.65 \pm 4.02 *$ & $138.86 \pm 8.20 *$ & $64.75 \pm 2.01$ & $21.81 \pm 2.36$ \\
\hline
\end{tabular}

Note: The present value of Melientha crude extract and fractions against ABTS and DPPH radicals and their total phenolic (TP) and total flavonoid (TF) contents are presented as mean \pm SD. The differences were considered significant at the level of $P<0.05\left(^{*}\right)$. The "-" mean not detected. 
The total phenolic contents (TP) of ethanol extract and fractions from ethanol extract were analyzed and expressed as milligram gallic acid equivalent per gram extract $(\mathrm{mg}$ $\mathrm{GE} / \mathrm{g}$ ). It was found that the ethanol extract had the highest TP, which was equal to 149.87 \pm 2.72 of gallic acid. A high level of TP was also extracted from distilled water fraction as this fraction was shown to have TP at a level of $64.75 \pm 2.01 \mathrm{mg} \mathrm{GE} / \mathrm{g}$ of ext followed by W, EtOAc, $\mathrm{CH}_{2} \mathrm{Cl}_{2}$ and hexane fractions. The difference of ethanol extract was not considered significant at the level of $P<0.05\left(^{*}\right)$ to ascorbic acid of ABTS and DPPH assays. But the difference was showed by $\mathrm{W}, \mathrm{EtOAC}, \mathrm{CH}_{2} \mathrm{Cl}_{2}$ and hexane fractions to ABTS and DPPH assays. The total flavonoid content (TF) was determined by aluminium chloride colorimetric assay and expressed as catechin equivalent per gram extract (mg CE/g). A high level of TF was also found in the ethanol extract. The TF in this fraction was equal to $51.60 \pm 4.12 \mathrm{mg} \mathrm{CE} / \mathrm{g}$ of ext.

\section{Physical evaluation of formulated cream}

The physical evaluation such as color, homogeneity, phase separation, thermal stability, $\mathrm{pH}$, and viscosity of formulated cream was performed in Table 3 . There were not shows the difference to the base cream ( $\mathrm{F}-1)$. There were also show the same range of $\mathrm{pH}$ and viscosity to $\mathrm{F}-1$. The $\mathrm{pH}$ of cream was determined to examine the possible side effects due to acidic or alkaline $\mathrm{pH}$, which can leads to irritation of skin and influence the rate of hydration of polymer. In general, the cream should have pH 6-9 (Donglikar and Deore, 2017).

Table 3. Physical evaluation of formulated cream.

\begin{tabular}{llllll}
\hline Physical evaluation & F-1 & F-2 & F-3 & F-4 & F-5 \\
\hline Color & No change & No change & No change & No change & No change \\
Homogeneity & Yes & Yes & Yes & Yes & Yes \\
Oil phase separation & No & No & No & No & No \\
Liquidify separation & No & No & No & No & No \\
Thermal stability & Stability & Stability & Stability & Stability & Stability \\
pH & 7.0 & 6.9 & 6.9 & 6.9 & 6.9 \\
Viscosity (cP) & 28470 & 30054 & 30108 & 30242 & 30477 \\
\hline
\end{tabular}

All formulations had increasing viscosity values after storage in freeze-thaw condition. All samples were oil-in-water creams; hence, their water contents might lose at fluctuated temperatures. Therefore, the suggested storage condition for these products should be at constant temperature. Furthermore, it was obviously found that the viscosity values of the sunscreen creams were directly related to the obtained SPF values. The formulations with suitable viscosity could provide more adhesiveness and spreading efficiency. No phase separation and change in color as well as odor were observed in all samples after stability test; however, they seemed to be more viscous. From the results it is observed the given formulations are relatively stable at accelerated temperature and humidity.

\section{Sun protection factor (SPF)}

A sunscreen protection is popular mean among various regions of world. Efficiency of sunscreens is expressed in the form of SPF. The absolute protection performance of a sun care product against erythermal-effective UV radiation was calculated from the measured in vitro transmittance and weighted with the erythema action spectrum and with the "standard" output spectrum of a UV solar simulator used for SPF testing. The SPFs of the formulated creams were compared with the cream with commercial sunscreen agent (PABA) (Figure 2). The concentration rang of PABA was $1.000 \%$ $8.000 \% \mathrm{~W} / \mathrm{V}$. The PABA at concentration $8.000 \% \mathrm{~W} / \mathrm{V}$ gave the highest SPF value $(9.47$ $\pm 0.24)$. SPF of formulated extract found to be higher, which indicates synergism and compatibility of excipients too. The differences were considered significant at the level of $P<0.05\left(^{*}\right)$ to positive control. These results reveal that the prepared formu-lations have good SPF which can be claim as a good sun protection activity. 


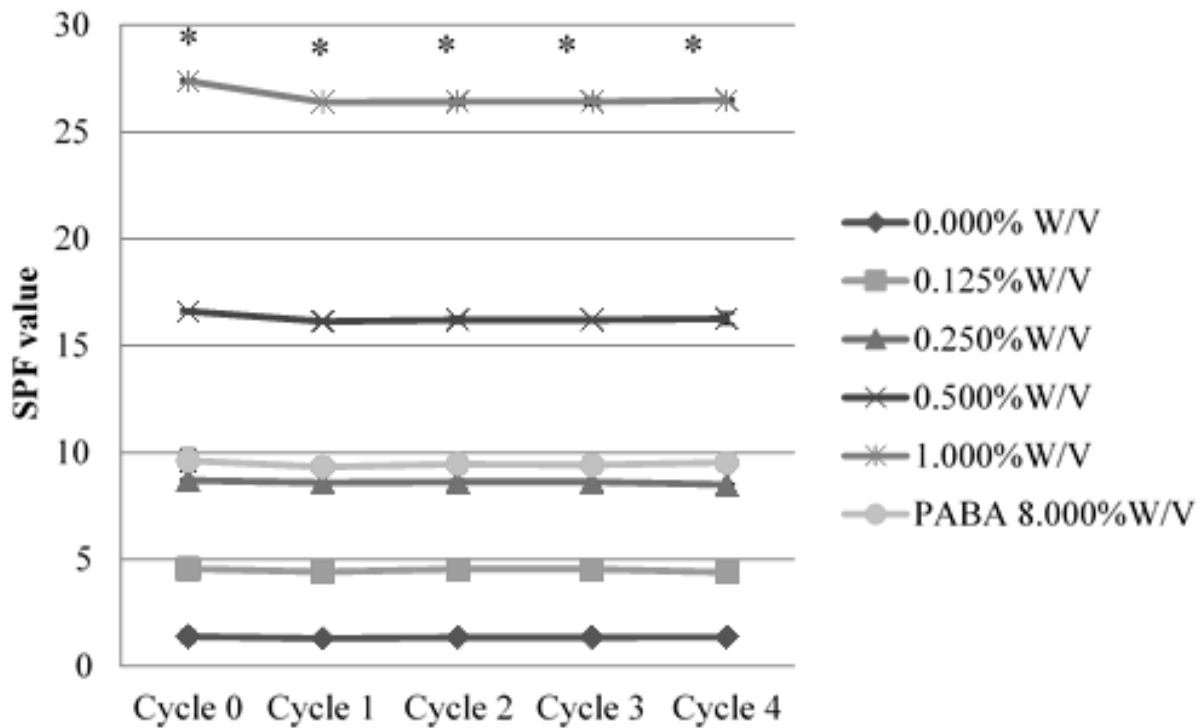

Figure 2. SPF values of Melientha ethanol extract at various concentrations. The crude extract of Melientha at $1.000 \% \mathrm{w} / \mathrm{v}$ showed the highest SPF value $(26.61 \pm 0.10)$. Note: The differences were considered significant at the level of $P<0.05(*)$.

\section{GC-MS analysis}

Ethanol extract of Melientha appeared as viscous yellow liquids with a percentage yield of 0.24-2.55 (w/w), respectively. These extracts were subjected to detailed GCMS analysis in order to investigate the volatile constituents. The key components were identified by GC-MS, their relative area percentages (RAP) and their retention (RT) indices are summarized in Figure 3 and Table 4. A total of 92 constituents representing in the Melientha extracts. The five components were established as related to antioxidant and sunscreen activities were reported.

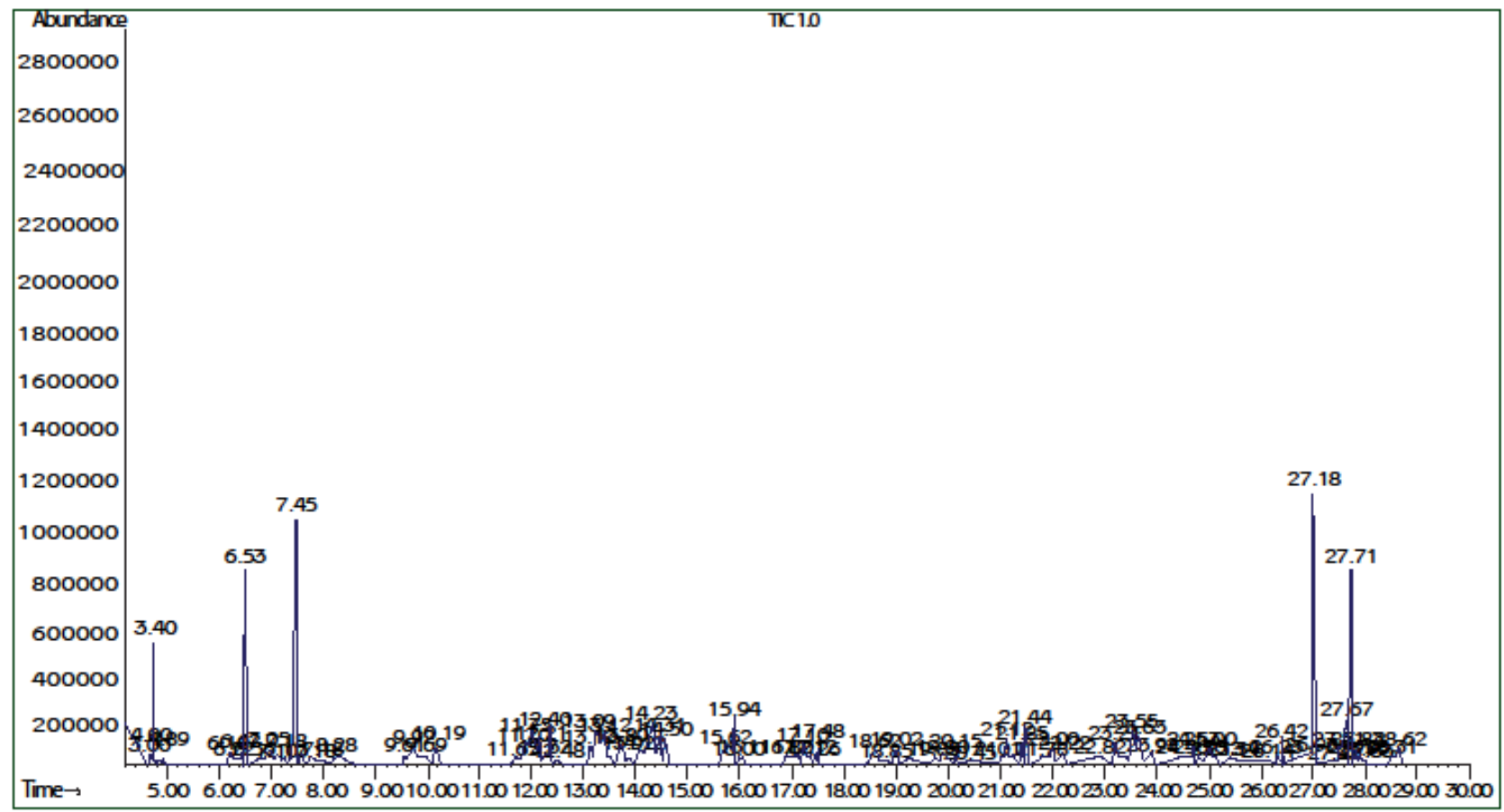

Figure 3. Total ionic chromatogram of ethanol crude extract of Melientha. 
Table 4. GC-MS analysis of Melientha ethanol extracts at various concentrations.

\begin{tabular}{|c|c|c|c|c|}
\hline No. & RAP & RT & Name & Properties \\
\hline 1 & & 3.40 & Cinnamic $\operatorname{acid}\left(\mathrm{C}_{9} \mathrm{H}_{8} \mathrm{O}_{2}\right)$ & $\begin{array}{l}\text { - Antioxidant (Li et al., 2014) } \\
\text { - Inhibition of tyrosinase (Garcia-Jimenez } \\
\text { et al., 2018) } \\
\text { - UV absorption (Li et al., 2017) }\end{array}$ \\
\hline 2 & & 6.53 & $\begin{array}{l}\text { 4-hydroxy-3-methoxycinnamic } \\
\text { alcohol }\left(\mathrm{C}_{10} \mathrm{H}_{12} \mathrm{O}_{3}\right)\end{array}$ & $\begin{array}{l}\text { - Antioxidant (Shang et al., 2015) } \\
\text { - Inhibition of tyrosinase (Garcia-Jimenez } \\
\text { et al., 2018) } \\
\text { - UV protection (El-Seedi et al.,2018) }\end{array}$ \\
\hline 3 & & 7.45 & 2-methylhydroquinone $\left(\mathrm{C}_{7} \mathrm{H}_{8} \mathrm{O}_{2}\right)$ & $\begin{array}{l}\text { - Skin depigmentation (Couteau and } \\
\text { Coiffard, 2016) }\end{array}$ \\
\hline 4 & & 27.18 & dl-alpha-Tocopherol $\left(\mathrm{C}_{29} \mathrm{H}_{50} \mathrm{O}_{2}\right)$ & $\begin{array}{l}\text { - } \text { Moisturizing agent (Pinto et al., 2018) } \\
\text { - } \text { Antioxidant (Caddeo et al., 2018) }\end{array}$ \\
\hline 5 & & 27.71 & Beta-carotene $\left(\mathrm{C}_{40} \mathrm{H}_{56}\right)$ & $\begin{array}{l}\text { Moisturizing agent (Boran, 2018) } \\
\text { Antioxidant (Gimenez-Rota et al., 2019) }\end{array}$ \\
\hline 6 & 49.08 & - & Others* & - - \\
\hline
\end{tabular}

Note: others* are showed the homology less than $80 \%$ to the reference databases.

\section{DISCUSSION}

Melientha extract has been reported to possess various bioactive compounds such as terpenes, flavonoids and polyphenols, which are related to its potent antioxidative activities (Charoenchai et al., 2015). This active fraction has been linked to the solvent polarity that can extract different fractions of polar/nonpolar constituents out of the plant (Saansoomchai et al., 2018). The Moringa oleifera extracts that found in this area also showed the antioxidant activities (Fitriana et al, 2016). The preliminary study found that the ethanol extract of Terminalia glaucescens showed the potency to scavenge of free radical (Olorunjuwon-Olugbami et al., 2015). On the other hand, the extract could modulate the biochemical metabolism as a result of the antioxidant effect and antioxidant compounds. The phenolic compounds and flavonoids had the potential to scavenge free radical (Hashim et al., 2011; Orhan et al., 2013). The antioxidant compounds that were found in the Melientha extracts related with antioxidant properties (Nurlaily et al., 2012). The antioxidant studies and antioxidant compounds of Melientha extract were belong to previous study (Kanlayavattanakul et al., 2012). Melientha leaf extract in ethanol fraction also showed a sunscreen property to UVB. Likewise, using the same protocol as the present study, one acetonic extract of the lichen Lasallia pustulata was found to have SPF maxima of 5.52 (Lohézic-Le Dévéhat et al., 2013). In a more generalistic point of view, the common feature of UV-absorbing secondary metabolites is the presence of aromatic or conjugated bond structures as it is found in plant that has phenolic or flavonoid substances. These molecules are one of the most effective UV radiation absorbers (Celis-Plá et al., 2016; Lann et al., 2016). In earlier study of Parzonko and Kiss (2019) showed that cosmetic formulation with herbal extracts protects human fibroblast against UV-A radiation in vitro. Moreover, the formulation with plant extracts could maintain the moisturizer of dry skin (Kapoor and Saraf, 2010). The photoprotective capacities of plant extracts such as polyphenols have been demonstrated in previous studies (Hu et al., 2017). Moreover, the plant extracts that showed antioxidant activities with antioxidant compounds can protect against the range of UV-B (Kanlayavattanakul et al., 2012). Indeed, using a similar in vitro UV method, three sunscreen emulsions with ethyl acetate plant extracts (10\%wt.) were tested in vitro (Jarzycka et al., 2013) and authors obtained SPF value $26.61 \pm 0.10$. Pervious study found the vegetable oil such as pomegranate oil and shea oil showed the UV protection effect (Montenegro and Santagati, 2019) but those oils were not found in Melientha extract and its fractions. By the studied of Caddeo et al., 2018 found that vitamin $E$ show UV protection activity by antioxidant effect and improve skin regeneration (Caddeo et al., 2018). The formulated cream with Melientha extract did not show the physical changes when compared to cream base. The dominant 
components that were related to cosmetic were 2-methylhydroquinone, cinnamic acid, 4-hydroxy-3-methoxycinnamic alcohol, alpha-tocopherol and beta-carotene. By the declare of substance by FDA, the group of cinamate and benzophenone can be used as the cosmetic formulation. These substances can be claimed to rise up the SPF value (Kanlayavattanakul et al., 2012). 2-methylhydroquinone is classified in a group of hydroquinone which famous for treating hyperpigmentation of melanogenesis. Moreover, it has antioxidant and anti-inflammatory effects (Shang et al., 2015; Couteau and Coiffard, 2016). Cinnamic acid and 4-hydroxy-3-methoxycinnamic alcohol are claim as the sunscreen agent were found in the Melientha extract. Cinnamic acid is another substance which is used in cosmetic formula. Cinnamic acid was claim as antioxidant, inhibition of tyrosinase, and UV absorption properties ( $\mathrm{Li}$ et al., 2014; Shang et al., 2015; Couteau and Coiffard, 2016; Li et al., 2017; Garcia-Jimenez et al., 2018) With those properties cinnamic acid and derivatives are allowed to use in cosmetic formula with regard to factors such as popularity, safety, and productiveness for cosmetic purposes (Sakamoto et al., 2017). Vitamin E or alpha-tocopherol has been attributed to beneficial influence on skin and most commonly used as compositions of cosmetic products. With antioxidants and moisture effects, vitamin $\mathrm{E}$ was used as raw material of manufacturer to claim as natural ingredient (Caddeo et al., 2018; Pinto et al., 2018). $\mathrm{B}$-carotene is the one of antioxidant substance. This dominant property is numberous used in cosmetic ingredient which was developed the efficient for treating all skin types (Boran, 2018; Gimenez-Rota et al., 2019). By our data, ethanol Melientha extract is a good natural resource for sunscreen cosmetic product.

\section{CONCLUSION}

Melientha extract has been reported to possess various bioactive compounds such as terpenes, flavonoids and polyphenols, which are related to its potent antioxidative activities. On the other hand, the extract could modulate the biochemical metabolism as a result of the antioxidant effect and antioxidant compounds. Melientha leaf extract in ethanolic crude extract also showed a sunscreen property to UV-B. The formulated cream with Melientha extract did not show the physical changes when compared to cream base. Cinnamic acid and 4-hydroxy-3-methoxycinnamic alcohol are claim as the sunscreen agent were found in the Melientha extract. By our data, ethanol Melientha extract is a good natural resource for sunscreen cosmetic product.

\section{ACKNOWLEDGEMENTS}

The authors would like to thank the Bioassay Research Unit, Department of Biochemistry, Faculty of Medicine, Chiang Mai University for instrumental supports and acknowledge to Professor Dr. T. Randall Lee, Department of Chemistry, University of Houston and Dr. Teera Watcharamongkol, the taxonomist of Faculty of Science and Technology, Kanchanaburi Rajabhat University for suggestions.

\section{REFERENCES}

Abramovič, H., Grobin, B., Ulrih, N.P., and Cigić, B. 2018. Relevance and standardization of in vitro antioxidant assays: ABTS, DPPH, and Folin-Ciocalteu. Journal of Chemistry. 2018: 1-10.

Boran, R. 2018. Investigations of anti-aging potential of Hypericum origanifolium Willd. for skincare formulations. Industrial Crops and Products. 118: 290-295.

Caddeo, C., Manca, M.L., Peris, J.E., Usach I., Diez-Sales, O., Matos, M., FernàndezBusquets, X., Fadda, A.M., and Manconi, M. 2018. Tocopherol-loaded transfersomes: In vitro antioxidant activity and efficacy in skin regeneration. International Journal of Pharmaceutics. 551: 34-41. 
Celis-Plá, P.S., Bouzon, Z.L., Hall-Spencer, J.M., Schmidt, E.C., Korbee, N., and Figueroa, F.L. 2016. Seasonal biochemical and photophysiological responses in the intertidal macroalga Cystoseira tamariscifolia (Ochrophyta). Marine Environmental Research. 115: 89-97.

Charoenchai, L., Settharaksa, S., Madaka, F., and Sueree, L. 2015. Evaluation of the antioxidant activities, total phenolic and flavonoid contents of Meliantha suavis PIERRE. Bulletin of Health, Science and Technology, 13: 29-37.

Charoenchai, L., Settharaksa, S., Songsak, T., Ruangrangsee, N., and Kraisintu, K. 2013. Phytochemical screening test of Meliantha suavis PIERRE and Urobotyra siamensis Hiepko extracts. Bulletin of Health, Science and Technology, 11: 13-20.

Couteau, C., and Coiffard, L. 2016. Overview of skin whitening agents: drugs and cosmetic products. Cosmetics. 3(3), 27: 1-16.

Donglikar, M.M., and Deore, S.L. 2017. Development and evaluation of herbal sunscreen. Pharmacognosy Journal. 9: 83-97.

El-Seedi, R.H., Taher, E.A., Sheikh, B.Y., Anjum, S., Saeed, A., Alajmi, M.F., Moustafa, M.S., Al-Mousawi, S.M., Farag, M.A., Hegazy, M.E.F., and et al. 2018. Hydroxycinnamic acids: natural sources, biosynthesis, possible biological activities, and roles in Islamic medicine. Studies in Natural Products Chemistry. 55: 269-292.

Fitriana, W.D., Ersam, T., Shimizu, K., and Fatmawati, S. 2016. Antioxidant activity of Moringa oleifera extracts. Indonesian Journal of Chemistry. 16: 297-301.

Garcia-Jimenez, A., García-Molina, F., Teruel-Puche, J.A., Saura-Sanmartin, A., GarciaRuiz, P.A., Ortiz-Lopez, A., Rodríguez-López, J.N., Garcia-Canovas, F., and Munoz-Munoz, J. 2018. Catalysis and inhibition of tyrosinase in the presence of cinnamic acid and some of its derivatives. International Journal of Biological Macromolecules. 119: 548-554.

Gimenez-Rota, C., Palazzo, I. and Scognamiglio, M.R. 2019. $\beta$-Carotene, a-tocoferol and rosmarinic acid encapsulated within PLA/PLGA microcarriers by supercritical emulsion extraction: Encapsulation efficiency, drugs shelf-life and antioxidant activity. The Journal of Supercritical Fluids. 146: 199-207

Hashim, P., Sidek, H., Helan, M.H.M., Sabery, A., Palanisamy, U.D., and Ilham, M. 2011. Triterpene composition and bioactivities of Centella asiatica. Molecules. 16: $1310-1322$.

Hatthakitpanichakul, N., and Tangjitjaroenkul, J. 2007. Preliminary studies of the inhibition of plant pathogens using active compound from plants in Si Racha Campus. In Kasetsart University. Proceedings of $45^{\text {th }}$ Kasetsart University Annual Conference. Bangkok, 30 January - 2 February 2007. Bangkok, Thailand. 600608.

Hu, S., Zhang, X., Chen, F., and Wang, M. 2017. Dietary polyphenols as photoprotective agents against UV radiation. Journal of Functional Foods. 30: 108-118.

Jarzycka, A., Lewińska, A., Gancarz, R., and Wilk, K.A. 2013. Assessment of extracts of Helichrysum arenarium, Crataegus monogyna, Sambucus nigra in photoprotective UVA and UVB; photostability in cosmetic emulsions. Journal of Photochemistry and Photobiology. B, Biology. 128: 50-57.

Kanlayavattanakul, M., Ospondpant, D., Ruktanonchai, U., and Lourith, N. 2012. Biological activity assessment and phenolic compounds characterization from the fruit pericarp of Litchi chinensis for cosmetic applications. Pharmaceutical Biology. 50: 1384-1390.

Kapoor, S., and Saraf, S. 2010. Formulation and Evaluation of moisturizer containing herbal extracts for the management of dry skin. Pharmacognosy Journal. 2: 409-417.

Lann, K.L., Surget, G., Couteau, C., Coiffard, L., Cérantola S., Gaillard F., Larnicol, M., Zubia, M., Guérard, F., Poupart, N., and et al. 2016. Sunscreen, antioxidant, and bactericide capacities of phlorotannins from the brown macroalga Halidrys siliquosa. Journal of Applied Phycology. 28: 3547-3559.

Li, Y., Dai, F., Jin, X.L., Ma, M.M., Wang, Y.H., Ren, X.R., and Zhou, B. 2014. An effective strategy to develop active cinnamic acid-directed antioxidants based on elongating the conjugated chains. Food Chemistry. 158: 41-47. 
Li, Y., Tang, L., Ma, X., Wang, X., Zhou, W., and Bai, D. 2017. Synthesis and characterization of $\mathrm{Zn}-\mathrm{Ti}$ layered double hydroxide intercalated with cinnamic acid for cosmetic application. Journal of Physics and Chemistry of Solids. 107: 62-67.

Lohézic-Le Dévéhat, F., Legouin, B., Couteau, C., Boustie, J., and Coiffard, L. 2013. Lichenic extracts and metabolites as UV filters. Journal of Photochemistry and Photobiology. B, Biology. 120: 17-28.

Montenegro, L., and Santagati, L.M. 2019. Use of vegetable oils to improve the sun protection factor of sunscreen formulations. Cosmetic. 6: 1-10.

Nurlaily, A., Noor-Baitee, A.R., and Musalmah, M. 2012. Comparative antioxidant and anti-inflammatory activity of different extracts of Centella asiatica (L.) Urban and its active compounds, asiaticoside and madecassoside. Medicine \& Health. 7: 62-72.

Olorunjuwon-Olugbami, J., Gbadegesin, M.A., and Odunola, O.A. 2015. In vitro free radical scavenging and antioxidant properties of ethanol extract of Terminalia glaucescens. Pharmacognosy Research. 7: 49-56.

Orhan, I.E., Atasu, E., Senol, F.S., Ozturk, N., Demirci, B., Das, K., Das, K. and Sekeroglu, N. 2013. Comparative studies on Turkish and Indian Centella asiatica (L.) Urban (gotu kola) samples for their enzyme inhibitory and antioxidant effects and phytochemical characterization. Industrial Crops and Products. 47: 316-322.

Parzonko, A., and Kiss, A.K. 2019. Caffeic acid derivatives isolated from Galinsoga parviflora herb protected human dermal fibroblasts from UVA-radiation. Phytomedicine. 57: 215-222.

Pinto, F., Barros, D.P.C., and Fonseca, L.P. 2018. Design of multifunctional nanostructured lipid carriers enriched with a-tocopherol using vegetable oils. Industrial Crops and Products. 118: 149-159.

Saansoomchai P., Limmongkon, A., Surangkul, D., Chewonarin, T., and Srikummool, M. 2018. Enhanced VEGF expression in hair follicle dermal papilla cells by Centella asiatica Linn. Chiang Mai University Journal of Natural Sciences. 17: 25-36.

Sakamoto, K. Lochead, R.Y., Maibach, H.I., and Yamashita, Y. 2017. Cosmetic science and technology: theoretical principles and applications. Amsterdam: Elsevier.

Shang, Y.J., Liu, B.Y., and Zhao, M.M. 2015. Details of the antioxident mechanism of hydroxycinnamic acids. Czech Journal of Food Science. 33: 210-216.

Skotarczak, K., Osmola-Mankowska, A., Lodyga, M., Polanska, A., Mazur, M., and Adamski, Z. 2015. Photoprotection: facts and controversies. European Review for Medical and Pharmacological Science. 19: 98-112.

Sukprasansap, M., Charoenkiatkul, S., Judprasong, K., and Kangsadalampai, K. 2010. Effect of indigenous Thai plants on ethtl carbamate in somatic cells of Drosophilia melanogaster. Toxicology Letters. 196-S157-S158.

OPEN access freely available online

Chiang Mai University Journal of Natural Sciences [ISSN 16851994]

Chiang Mai University, Thailand

https://cmuj.cmu.ac.th 